\title{
OBITUARY
}

\section{G. Doran}

It is with regret that we learn of the death of Dr I. G. Doran. He died in December 2006 at the age of 83 years following a short illness.

Dr Doran was educated at the Methodist College Belfast and later received the degrees of $\mathrm{BSc}$ and $\mathrm{MSc}$ from Queen's University Belfast. He obtained his doctorate degree in geotechnics in 1947 from Queen's University Belfast (QUB), and most probably the first $\mathrm{PhD}$ awarded in geotechnics in the UK. His PhD research focused on the secondary consolidation of clays. Dr Doran was naturally interested in geotechnical engineering and, as such, his expertise spread from practical geotechnics to research and development within the academic sphere.

He established the Northern Ireland Material Testing Station at QUB, where he became a young lecturer in geotechnics in 1947 . He founded his engineering consulting practice in 1953 and his early private practice was mainly in foundations and structures, which included the structural design of many notable public buildings. His firm gradually expanded and in 1972 became a partnership, subsequently widely known as I G Doran and Partners. He was a founding member and subsequently Chairman of the Northern Ireland Building Regulations Advisory Committee. In 1981, the Queen honoured him with an OBE in recognition of his services to the construction industry. His enthusiasm for research and development in the field of geotechnics was unique and unrelenting. His return to QUB in September 1991 began with the appointment of Honorary Professor. He continued in this role until his recent death and, during that time, contributed significantly towards research in geotechnics at QUB. He has authored many publications in international geotechnical journals, including Geotechnique, and they are listed below.

Dr Doran's opinions on professional matters and affairs could always be relied upon to be stimulating and demanding. He greatly enjoyed good-humoured controversy, often endearing himself to his friends and colleagues when gathered around a dinner table after an animated debate. At the banquet at the Second International Conference on Soil Mechanics and Foundation Engineering in 1947, he collected autographs of many of the leading personalities of the time. This was one of his treasured possessions and we have included a copy.

Dr Doran is survived by his wife Ainslie, his two daughters and his son. Alas, he is no longer with us but his memories will live on in those who were guided by him.

Vinayagamoorthy Sivakumar and Danny Glynn

\section{PUBLISHED WORK}

Doran, I. G. (1992). The subsoils of Northern Ireland. The Structural Engineer, 70, 135-138.

Cumming, S., Doran, I.G. Sivakumar, V. and Hughes, D (1998). Characterization of the subsoil condition at Swann's Bridge, Northern Ireland. Proceedings of the First International Conference on Site Characterization, ISC '98, Atlanta, Georgia, USA, pp 353-358

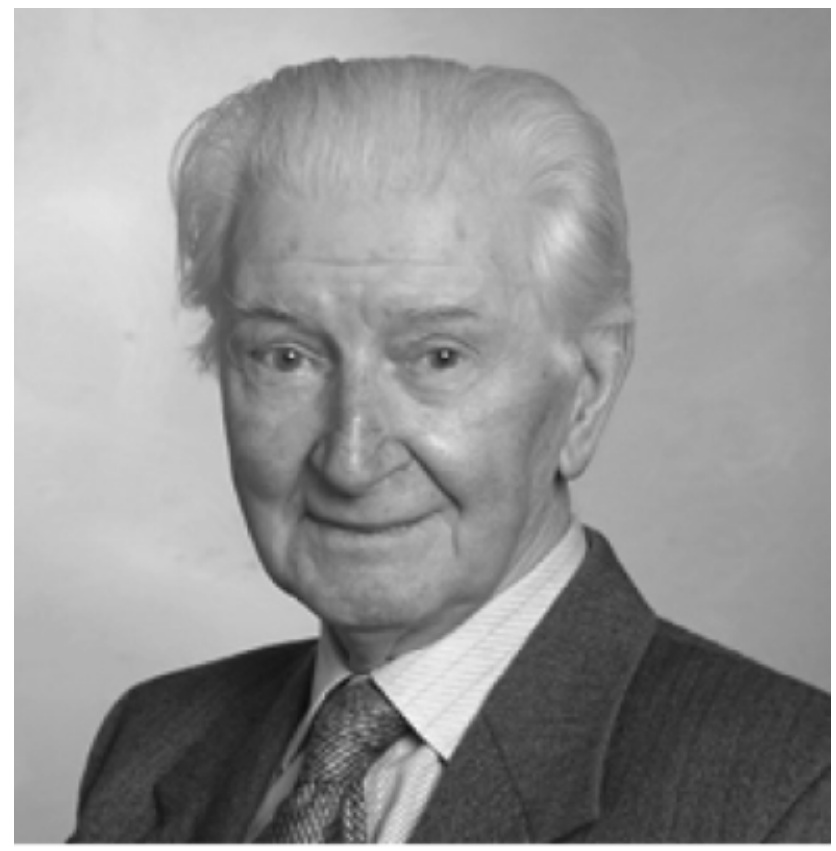

Dr I. G. Doran, 1923-2006

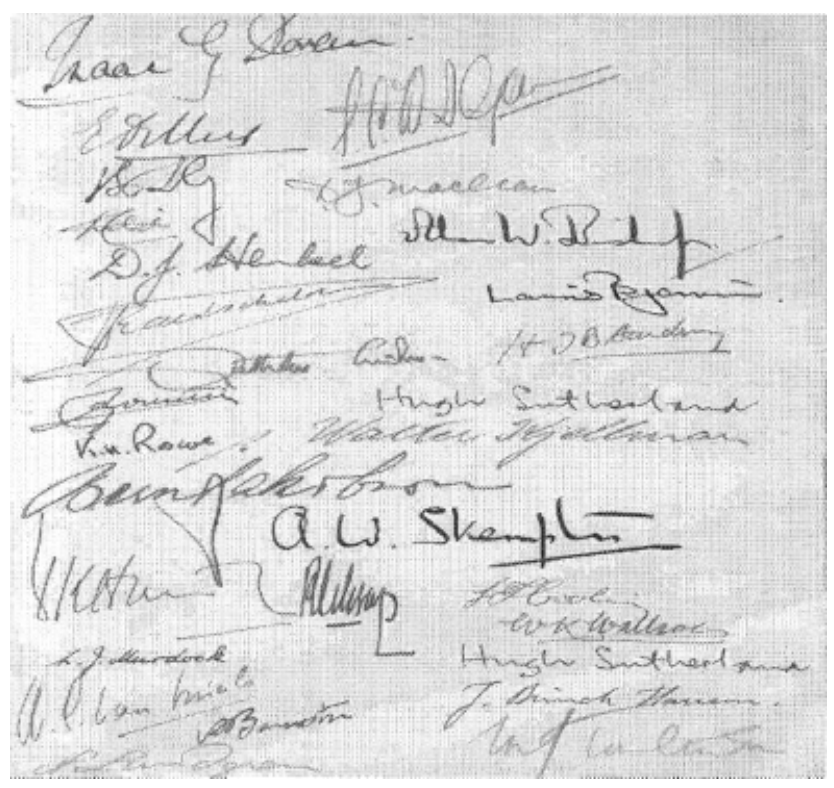

Doran, I. G., Sivakumar, V., Graham, J., and Johnson, A. (2000) Estimation of in-situ stresses using anisotropic elasticity and suction measurements. Geotechnique, 50, No. 2, pp. 189-196.

Sivakumar, V. and Doran, I. G. (2000). Yielding Characteristic of compacted clay. Mechanics of Cohesive-Frictional Materials, 5, 291-303.

Sivakumar, V., Doran, I. G., Graham, J. and Johnson, A. S. (2001). 
The effect of anisotropic elasticity on the yielding characteristics of overconsolidated natural clay. Canadian Geotechnical Journal, 38, pp. 125-137.

Sivakumar, V., Doran, I. G. and Graham, J. (2002). Particle orientation and its influence on the mechanical behaviour of isotropically consolidated reconstituted clay. Engineering Geology, 66, 197-209.

Sivakumar, V., Doran, I. G., Graham, J. and Navaneethan, T. (2002).
Relationship between $\mathrm{K}_{0}$ and overconsolidation ratio - a theoretical approach. Geotechnique, 52, No. 3, 225-230.

Cummings, S. J., Sivakumar, V., Doran, I. G. and Graham, J. (2003). Deep sampling and testing in soft stratified clay. Canadian Geotechnical Journal, 28, 575-586.

Navaneethan,T.,Sivakumar,V., Wheeler,S.J. and Doran, I.G (2005). Assessment of three methods of suction measurements in saturated clays. Geotechnical Engineering, 158, No. 1, 15-24. 